\title{
歩行路における歩行者挙動に関する研究 PEDESTRIAN MOVEMENTS ON FOOTWAYS
}

\author{
毛 利 正 光* - 塚 口 博 司** \\ By Masamitsu MŌRI and Hiroshi TSUKAGUCHI
}

\section{1. まえがき}

都市交通に対する多様な要求に応えるためには, 基幹 となる交通手段に対する計画ばかりでなく，よりきめ細 かな計画をも立案することが必要であり，歩行者に関す る交通計画の重要性も高まっている．歩行者交通は公共 交通に付随した端末徒歩や乗り換え時の徒歩，および主 として居住地での交通手段である徒歩を含んでいて, 歩 行者交通としてまとまったシステムをもつことが必要で ある・また，そのシステムが都市全体の総合交通システ ムの一環として位置付けられなければならない.

しかし，歩行者交通は非常に柔軟性に富んでおり，歩 行者はかなりの悪環境にも適応してきたので, 交通事故 等のように，その柔軟性をもってしても適応できないも のを除くと，交通計画に掞いて充分な配慮が払われてい なかったと考えられる.

このようなことを反映して, 歩行者交通, 特に歩行者 流動に関する研究は欧米ではかなり行われているもの の，わが国においては，建築物に付随した問題として扱 われた通路幅の諸元を決定するための研究等を除くと, あまり行われていない状態である. しかしながら，歩行 者交通が柔軟性に富んでいるといっても, 多くの場合, 歩行者が我慢するという形で，矛盾が吸収されてきたに すぎないように思われる．したがって，歩行者を主体的 にとらえた計画を立案するためには，歩行者の諸元にあ った設計基準が必要であり, そのためには, 歩行者交通 に関する特性を広範にかつ詳細に分析していくことがま ず必要となってくる.

\section{2. 従来の研究と本研究のねらい}

* 正会員 工博 大阪大学教授 工学部土木工学科

** 学生会員 工修 大阪大学大学院工学研究科土木工学専攻
歩行者流動に関する研究は, 建築物内の通路や階段に ついての諸元を決めるという要求から始められ，1937 年に木村ら ${ }^{1)}$ の研究がみられる. また, 駅構内の設計の ための研究2) 4) も長期間続けられている. このように歩 行者の流れについての研究は，わが国においても，かな り以前に遡ることができるが，屋外の歩行者を対象とし たものはあまり見あたらないようである.もっとも，混 合交通における歩行者の影響については早くから取り上 げられ ${ }^{5)}$ また近年，歩行者重視の立場から，細街路で の歩行者の挙動が研究されている ${ }^{6)}$. そこで, 歩道等に おける歩行者の挙動についての諸外国の研究について述 べると, これらの研究においてよく取り上げられている のは, 歩行速度の特性についてであり, それが外的な条 件によってどのように変化するかが論じられている.こ れらはおおむね自動車交通流の考え方を拉張したもので あって, 歩行者密度との関係について特に詳しく分析さ れている.

1958 年に Hankin と Wright ${ }^{7)}$ は歩行速度と歩行者 交通量とを実測し, 速度と密度, 密度と交通量の関係を 示している. 1968 年には Older ${ }^{8)}$ が商店街の歩道でカ メラを用いた実測から, 速度・密度・交通量の関係を求 めている. また, 1969 年には Navin と Wheeler ${ }^{9)}$ が 大学のキャンパス内で調査を行い, 上記の関係の他に通 行帯についても述べている. 1972 年には O'flaherty と Parkinson $^{10)}$ が商店街の歩道において, 直接移動に使わ れていない面積を除いて歩道幅員を修正し, 速度と密度 等の関係を求めている. このように歩行速度・歩行者密 度・歩行者交通量の関係の概略については述べられてい るが, 対象とした歩行者の属性等の問題もあり, 必ずし も明確には示されていないようである. また，1963 年 には Oeding ${ }^{11)}$ が, 1971 年には Fruin ${ }^{12)}$ が歩行者空間 のサービス水準についての研究を行っており, それ以降 のサービス水準についての研究 ${ }^{13)}$,14) の基礎となってい る. Fruin は歩行速度の変化と, 側方から流入する歩行 
者が流れを乱さずに横断できる確率等から，歩行路のサ 一ビス水準を設定している.

その他の速度特性については, Hoel ${ }^{15)}$ は性別, 気温,一 日のうちの時間帯による差について, Henderson ${ }^{16)-19)}$ は性別による速度分布形の差等について詳細に述へてい る.

さて, 歩行空間の整備をはかるためには, 歩行者流動 の特性を十分に考慮した合理的な設計基準を設定するこ とが必要となってくる，その場合，歩行者の流れにおい ては交通量が最大となるのは, 非常に混雑した状態のと きであるから，「どれだけの歩行者が通れるか」とい。 た容量関する検討だけでなく，「歩きやすさ」とい。 た質的な問題についても検討することが重要である。そ こで, 歩行者を一括して「流れ」としてとらえる立場 と，それぞれの歩行者を「一人一人独立したもの」とし てとらえる立場の両方から取り組むのが望ましいと思わ れる.

このような観点から，本稿では，歩行者の流れを巨視 的にとらえて歩行速度・歩行者密度・歩行者交通量の関 倸について詳細に分析するとともに，微視的にとらえた 歩行者の追越し現象や歩行者の到着状態についても分析 し，歩行者流動の諸特性について言及した．さらに，そ れらを総合して, 歩行路のサービス水準についても若干 の考察を行って, 歩行者空閣, 特に歩道の設計に関する 基礎資料とするものである.

\section{3. 歩行者流動の実測調査}

\section{（1） 調查の概要}

歩道および地下道における歩行者の挙動を明らかにす るために, 大阪市都心部の 6 地点（梅田 2 地点, 淀屋橋 2 地点, 本町, 天満橋) で通勤時の歩行者を対象として 実測調查を実施した．歩道では特に通勤時の歩行者を対 象とした場合, 歩行者密度が非常に高い状態は局所的に しか生じなかったために, 高密度のデータは地下道にお ける測定から取得することにした．調查は昭和 50 年 6 月から 12 月にかけて行い, 調查時間帯は出勤時の約 1 時間とした. 調查地点は障害物のない平坦で見通しのよ い真直ぐな地点を選定した. 幅員は歩道では $2.2 \mathrm{~m}$, $4.35 \mathrm{~m}, 4.45 \mathrm{~m}, 5.5 \mathrm{~m}$, 地下道では $1.2 \mathrm{~m}, 3.5 \mathrm{~m}$ で あった. 歩行速度・歩行者密度・歩行者交通量をそれぞ れ独自に求め, 合わせて追越し現象について解析する必 要上から, 歩行者の流れを鳥瞰できる位置に設置した 8 ミリカメラを用いて, 毎秒 1 コマのコマ落とし撮影を 行った．ただし，地下道では撮影上の制約から 8 ミリカ メラは使用しにくいので，文献 7) で採用されている方
法を用い，現地で歩行者交通量と平均歩行速度を測定し た. すなわち, 2 人の測定者 $\mathrm{A}, \mathrm{B}$ が測定区間 $l$ の両 端に立ち, Aが歩行者の流れにのって区間 $l$ を歩く時間 を測定する. 一方, Bはその間に眼前を通りすぎる人数 を測定するといらものである.

なお,ここで通勤時の歩行者を対象としたのは, 歩行 者の挙動は目的によって異なると思われ, 流れの特性に ついて考える場合には交通目的を限定すべきであるこ と，および通勤時の挙動には歩くこと以外の目的が少な く,スムーズで安定した流れを解析するのに適している と考えられるからである。

\section{(2) デー夕処理}

\section{a）歩道で撮影したデータ}

各地点で撮影した約 1 時間分のフィルムから歩行者の 流れがほぼ一様であると見なせる箇所を 1 分間分 $(60$ コマ）とり，これを 1 標本とした. 歩行者交通量は 1 分 間交通量で表わし，歩行速度の平均値および標準偏差の 変動を考慮して，任意抽出した 50 人の歩行者について $20 \mathrm{~m}$ の測定区間での歩行速度を測定した。なお，対向 者が存在しない箇所を選択するようにしたが，広幅員 (5.5 m) の歩道では一方向だけのデー夕を取得できなか ったので, 後述する方法で, 対象とした向きの歩行者が 占有する幅員を決定した.

b) 地下道で撮影したデータ

測定区間 $l \mathrm{~m}$ を $t$ 秒かかって測定者 $\mathrm{A}$ が通行する 間に，測定者 B が数えた人数を $q$ 人とし，

$$
V=l / t, \quad Q=q \times 60 / t
$$

として求めたデータを一標本とした。 なお， $l$ は現地の 状況によって 5〜10 m とした.

\section{（3）有効幅員について}

対向する歩行者がある場合，それぞれの向きの歩行者 が集団化する場合と集団化しない場合とがある．前者は 「避過する」, 後者は「透過する」と呼ばれている ${ }^{20)}$. 「避過する」場合には，それぞれの向きの歩行者によっ て歩道がどのような割合で分割されているかを示すこと ができる．歩行者密度が高くなると，ほとんどの場合 「避過する」ことが観察されるから，低密度の場合にも 「避過する」データだけを採用すれば，次のようにして 対向者が存在する場合の占有幅員を決定できる.

全歩道幅員 $(D=5.5 \mathrm{~m})$, 対向歩行者が占有する幅員 $(d[\mathrm{~m}])$, 全交通量 $(Q[$ 人/分 $])$, 対向交通量 $(q[$ 人/分 $])$ を用いると，

対向歩行者の歩道占有率 : $y=d / D$

対向交通量の全交通量に対する比: $x_{1}=q / Q$

となる. $y$ と $x_{1}$ には関数関倸があると思われ，それを 


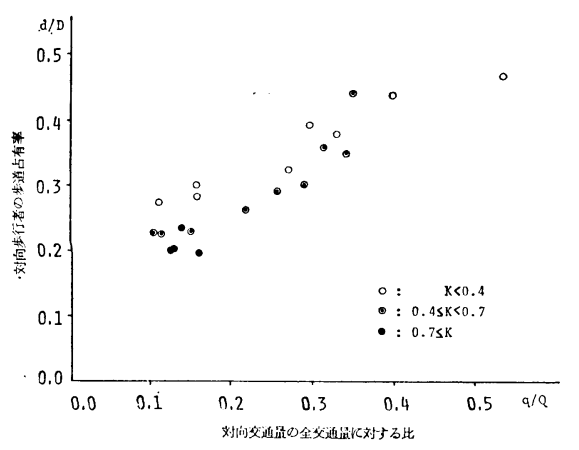

図一1 対向する歩行者の歩道占有率

表一1 相関係数表

\begin{tabular}{|c|c|c|}
\hline 重相関係 & 偏相関係数 & 単相関係数 \\
\hline $\mathrm{R} y, \mathrm{x} 1, \mathrm{x} 2=0.959$ & $\mathrm{R} \times 1 \mathrm{x}, \mathrm{x} 2=0.919$ & $\mathrm{Rx} 1, \mathrm{y}=0.918$ \\
\cline { 2 - 3 } & $\mathrm{R} \times 2 \mathrm{x}, \mathrm{x} 1=-0.699$ & $\mathrm{Rx} 2, \mathrm{y}=-0.698$ \\
\cline { 3 - 4 } & & $\mathrm{Rx} 1, \mathrm{x} 2=-0.498$ \\
\hline
\end{tabular}

示すと 図一1 のようになる．各データを密度をパラメ 一タとして 3 段階に分けてみると, 密度が高くなると $y$ の值が減少する傾向が見られる，そこで，

測定区間内の歩行者密度 : $x_{2}=P / D l$

ここで, $l:$ 測定区間長 $(20 \mathrm{~m})$

$$
P: \text { 区間内に存在する平均歩行者数 }
$$

も説明変数に加えると,

$$
y=0.551 x_{1}-0.127 x_{2}+0.232
$$

という 回帰式が得られ，相関係数は 表一1 に示すよう になる.この重回帰式の有意性および $x_{2}$ を説明変数に 加えたことの有意性をそれぞれ $F$ 検定, $t$ 検定で検定 すると,

$$
\begin{gathered}
F=103>F(2,18 ; 0.01)=6.01 \\
t=4.81>t(18 ; 0.01)=2.88
\end{gathered}
$$

のようになり，この回帰式を使用してもよいと考えられ る. そこで式 (1) を用いて占有幅員を求め, 4 章以下 の分析に使用した.この結果, $5.5 \mathrm{~m}$ の歩道の占有幅員 が 3.5 4.5 m となったので, 最終的に歩道では, 幅員 別にみて $3.5 \sim 4.5 \mathrm{~m}$ および約 $2 \mathrm{~m}$ の 2 種類のデータ が得られたことになる.

\section{4. 歩行者の流れの特性}

本章では歩行者の流れを巨視的にとらえて, 歩行者の 速度 $(V)$, 密度 $(K)$, 交通量 $(Q)$ の関係について検 討する.

（1）歩行速度, 歩行者密度, 歩行者交通量の関係 歩行者の流れは, 時間的にも空間的にも変化するが,
ここでは平均值的な取り扱いにより，その概略について 述べる.

速度 と密度の関係は 図一2 に示すとおりである.こ れによると, 自由歩行速度は毎秒約 $1.5 \mathrm{~m}$ であるが, 密度が増加するとともに直線的に徐々に低下して, $K=$ 1.5 人 $/ \mathrm{m}^{2}$ では毎秒 $1.1 \mathrm{~m}$ 前後となる. 密度が 1.5 人/ $\mathrm{m}^{2}$ 以上になると, 速度はいったん急激に低下寸るが, その後また緩やかに低下していくことがわかる. 速度と 密度の関係を表わす回帰式を求めると， $K<1.5$ 人 $/ \mathrm{m}^{2}$ の場合には式 (2), $K>1.5$ 人 $/ \mathrm{m}^{2}$ の場合には式 (3) が適している.

$$
\begin{aligned}
& V=-0.204 K+1.48 \\
& V=1.32 \log \frac{9.16}{K} \ldots
\end{aligned}
$$

式（2）および式（3）の相関係数はそれぞれ -0.864 ,

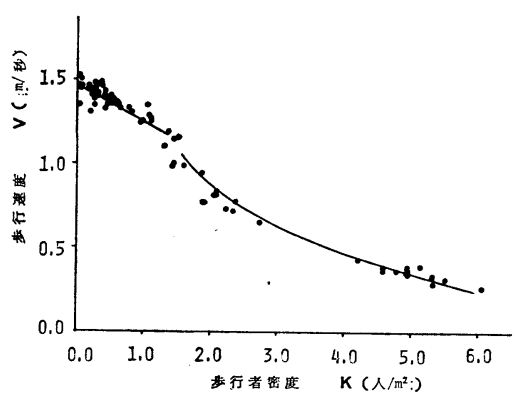

図一2 歩行速度と歩行者密度

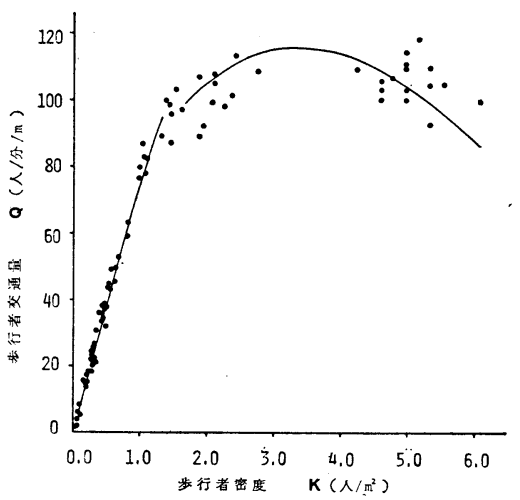

図一3 歩行者交通量と歩行者密度

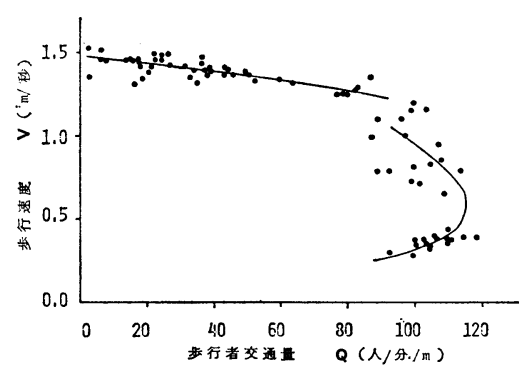

図-4 歩行速度と歩行者交通量 
-0.985 である. 密度と交通量, 速度と交通量の関係は それぞれ 図一3，4 に示すとおりである. 最大交通量が 生じるのは密度が 3 4 人 $/ \mathrm{m}^{2}$ のときであると思われ， そのときの速度は約 $0.5 \mathrm{~m} /$ 秒に低下しており, 非常に 混雑した状態であることがわかる.

さて, 従来, 歩行者の流れについても, 速度・密度 · 交通量の間に

$$
Q=K V
$$

なる関係が成立すると報告されているが，必ずしも明確 に示されているわけではないように思われる. 図一3，4 に，式（2）および式（3）を式（4）に代入して求めた曲 線を描いてみると, この曲線と実測值とはかなりよく適 合していることがわかる.これについて歩道で測定した 1.5 人 $/ \mathrm{m}^{2}$ 以下のデータを用いて, 定量的に検証してみ た. 図一5 に直接測定した速度 $(V)$ と密度, おょび式 (4) が成立つと仮定して求めた速度 $\left(V^{\prime}\right)$ と密度の関係 を示している. $V$ と $V^{\prime}$ について密度を補助因子とし て共分散分析を行らと, 表一2 のように $F$ 值は

$$
F=2.7<F(1,97,0.05)=3.9
$$

となり, $V$ と $V^{\prime}$ とは同じ集団に属しているとしてょ

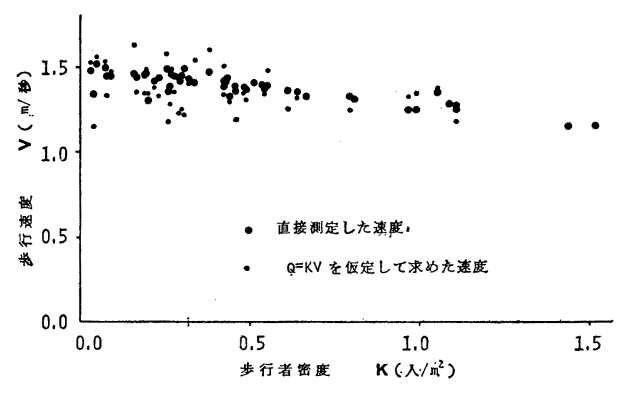

注：・が・に包含される場合は・のみ記入した

図一5 歩行速度と歩行者密度

\begin{tabular}{|c|c|c|c|c|c|}
\hline 要因 & 平方和 & 自由度 & 不偏分散 & 分散比 & 裹却領 域 \\
\hline 級間 & $\mathrm{Sa}=0.0193$ & 1 & $\mathrm{Va}=0.0193$ & \multirow{2}{*}{$F=2.7$} & \multirow{2}{*}{$\begin{array}{l}F(1,97,0.05) \\
\quad=3.9\end{array}$} \\
\hline 級内 & $\mathrm{Se}=0.692$ & 97 & $\mathrm{Ve}=0.00714$ & & \\
\hline
\end{tabular}

\section{表一2 分散分析表}

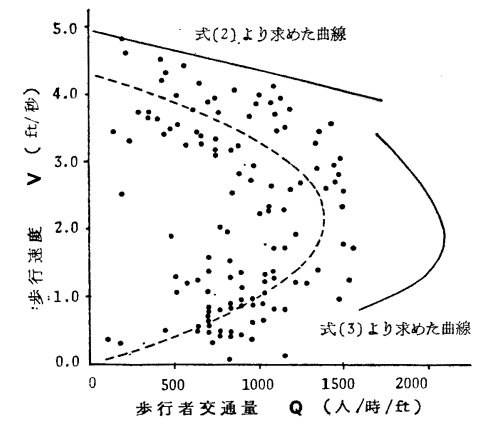

図一6 歩行速度と歩行者交通量（文献 8）より作成）
いと考えられる. したがって, 密度が 1.5 人 $/ \mathrm{m}^{2}$ 以上の 範囲については厳密には示せないが，少なくとも 1.5 人 $/ \mathrm{m}^{2}$ 以下の範囲においては式 (4) が成立すると考えて よいと思われる.

本稿では通勤時の歩行者を対象としているが, これま でにも商店街等での実測に基づいて速度と交通量の関係 が示されているので, これらのデータとの比較を行って みた. 図一6 は Older ${ }^{8)}$ がロンドンの商店街での実測か ら描いたものであるが, かなりの変動が見られる.この 図に本稿の回帰式 (2), (3) より求めた曲線を挿入する と, この曲線がほぼ包絡線のようになることがわかる.

通勤時のように, 歩行者が比較的急いでいる場合を除 くと, 低密度のときでもかなりゆっくり歩く歩行者がい るわけであるから, 種々の交通目的の歩行者について速 度と交通量の関係を図示すると, 図一6 のように通勤時 の歩行者についての曲線を包絡線として, その内部に他 の目的のデータが散らばるものと思われる.

\section{（2）歩行者密度からみた歩行速度特性}

前節では速度・密度・交通量の関係の概略について述 べたが,ここでは 1.5 人 $/ \mathrm{m}^{2}$ 以下の比較的低密度の場合 に抢ける速度の特性について述べることとしたい。

a) 歩行速度の変動

個々の歩行者の速度のちらばりをみるために, 速度の 標準偏差と密度の関係を 図一7 に示す. 速度と密度が 直線関係にあると考えられる $K<1.5$ 人 $/ \mathrm{m}^{2}$ の範囲に

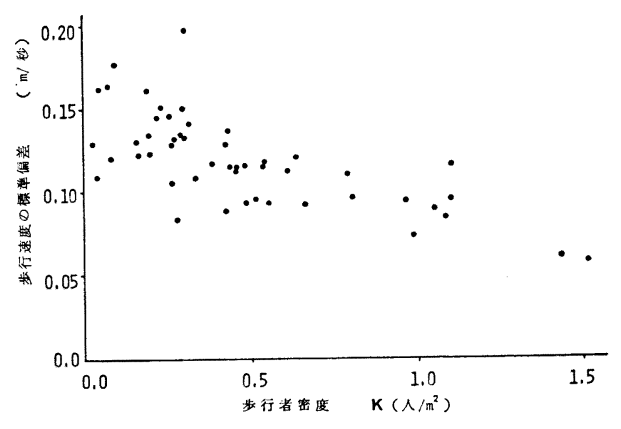

図一7歩行速度の標準偏差と歩行者密度

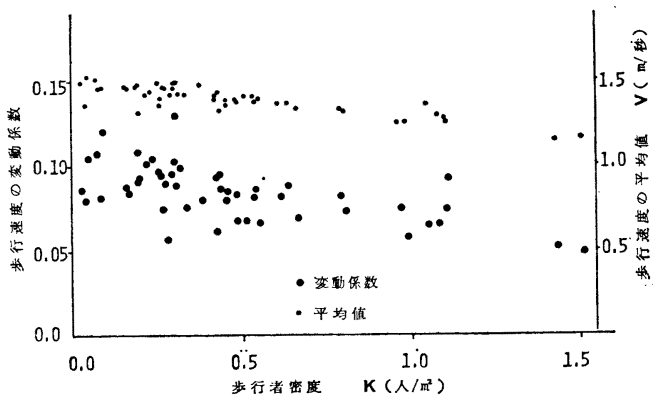

図一8歩行速度の変動係数と歩行者密度 
おいても標準偏差に大きな変動が現われ, 密度 0 人 $/ \mathrm{m}^{2}$ の近傍の自由歩行のできる状態では約 $0.15 \mathrm{~m} /$ 秒であ ったものが, 密度が 1.5 人 $/ \mathrm{m}^{2}$ になれば約 $0.05 \mathrm{~m} /$ 秒 と $1 / 3$ に減少していることがわかる.一般に平均値が小 さくなれば標準偏差も減少するから，平均値のまわりの 変動の状態を調べるためには, 変動係数で表わした方が よい. 速度の変動係数と密度の関係は 図一8 に示すと おりである. 密度の増加に伴い変動係数が減少している から, 密度が増加していくと, 速度の平均值は徐々に小 さくなるが, 平均值のまわりの変動は平均値の低下の度 合よりも急激に小さくなることがわかる.

また歩行速度の変動について別の観点から考察してみ た. 速度の最大值・最小值と密度の関係を図一9に示 す. 最小值は密度が増加しても 1.5 人 $/ \mathrm{m}^{2}$ 以下ではあま り変化しないが, 最大値の方はかなり減少していること がわかる.したがって, この間の平均速度の低下は, 主 として速度が大きい歩行者の速度低下によるものと考え られる.また, 速度の範囲 (二最大歩行速度一最小歩行 速度）と密度の関係は 図一10 に示寸とおりである. 速 度の範囲は低密度では $0.25 \sim 0.80 \mathrm{~m} /$ 秒とかなりの幅 をもっているが, 1.5 人 $/ \mathrm{m}^{2}$ 程度の密度では約 $0.25 \mathrm{~m} /$ 秒となっており, 変動幅は密度の増加にともなって減 少していくことがわかる.

b）歩行速度分布

歩行者密度がほぼ等しいデータを統合し，それらを正

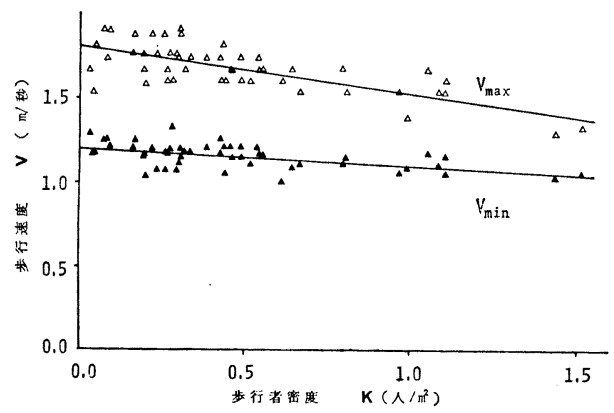

图一9最大歩行速度および最小歩行速度と歩行者密度

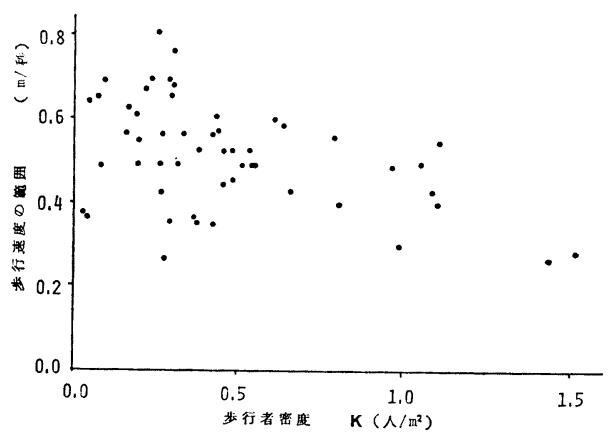

图一10 歩行速度の範囲之歩行者密度

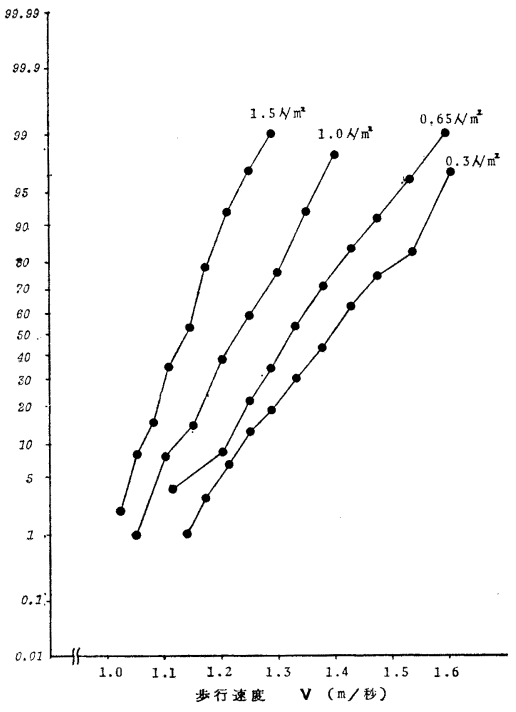

図一11歩行速度分布

規確率紙上にプロットしたものが 図一11 である.低密 度においては多少の変動があるものの, 扔拉むね直線と 見なせるから，歩行速度はそれぞれの密度で近似的に正 規分布で表わされると考えられる。

\section{5. 歩行者の到着分布特性}

本章および次章は，歩行者を巨視的に「流れ」として とらえるのではなく, 微視的な視点からその動きを検討 したものである。

\section{（1）到着分布について}

前章では, ある断面を 1 分間に通過する歩行者数を歩 行者交通量として分析したが，ここでは，1秒間に通過 する人数を対象として到着分布の特性について述べるこ ととしたい.

ある空ロへの客の到着状態には, ランダム型の場合, 規則型の場合, および中間型の場合があり,それぞれの 型に対応寸る確率密度は指数分布, 単位分布, アーラン 分布となる. 到着分布は到着間隔分布および到着人数分 布のいずれでも表わせるが，両者は相互に変換可能であ るから, 実測しやすい到着人数分布について考えてみる こととする. 一般に 1 秒間当りの到着人数分布は

$$
\begin{aligned}
U_{n}= & e^{-l \lambda} \sum_{i=0}^{l-1}\left[\left(1-\frac{i}{l}\right) \frac{(l \lambda)^{n l-i}}{(n l-i) !}\right. \\
& \left.+\left(1-\frac{i+1}{l}\right) \frac{(l \lambda)^{n l+i+1}}{(n l+i+1) !}\right]
\end{aligned}
$$

と表わされる ${ }^{21)}$.ここで,

$\lambda:$ 平均到着人数 (人/秒)

$l:$ 位相 
である.なお， $l=1$ のとき式（5）は

$$
U_{n}=e^{-\lambda} \frac{\lambda^{n}}{n !}
$$

となりポアソン分布となる. また, $l=\infty$ のときは単位 分布となる.

\section{（2）歩行者の到着人数分布}

歩行者密度と歩道幅員とによって, 歩行者の到着分布 がどのように変化するかを検討してみた，歩行者密度が ほぼ等しいデータを統合し，各密度ごとに式 (5) との 適合度を $\chi^{2}$ 検定で検定し， $\chi^{2}$ 值が最小となる位相 $l$ を求めた.この位相と密度の関係は 図一12 に示すとお りである. 幅員が $3.5 \sim 4.5 \mathrm{~m}$ の場合には 0.6 人 $/ \mathrm{m}^{2}$ 程 度までは $l=1$ のアーラン型の分布, すなわちポアソン 分布に適合し, $K=1$ 人 $/ \mathrm{m}^{2}$ では $l=2, K=1.5$ 人 $/ \mathrm{m}^{2}$ では $l=3$ のアーラン型の分布に適合することがわか る. 0.8 人 $/ \mathrm{m}^{2}$ 付近では $l=1, l=2$ との適合度がほぼ 等しくなっている. 一方, 幅員が約 $2 \mathrm{~m}$ の場合には, 0.3 人 $/ \mathrm{m}^{2}$ 以下においても $l=2$ になっている. したが って, 位相は歩行者密度と歩道幅員によって変化すると 考えられる.

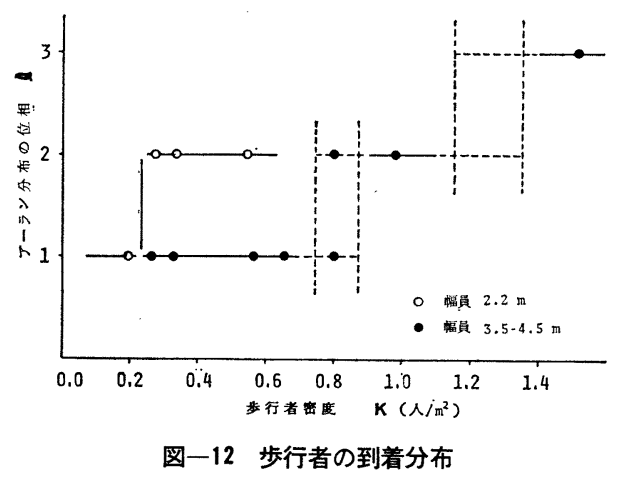

この位相は, 待ち行列理論においては客の「到着調整 機関 ${ }^{21)}$ を表わすとされているが, 歩行者流動の場合に おける意味を考えてみることにする. 歩行者の密度が増 加するにつれて, 歩行者 1 人当りが使用できる面積が減 少していくから, 歩行の自由性が失われていく. 一方, 幅員が狭くなると, 横断方向に並べる人数が減り, 通行 する位置が限定されてくるから, 歩行の自由性が低下し ていく.そこで, 歩行の自由性が低下すると, 位相が大 きくなるわけで, 位相によって混雑の程度, いい換える と，歩行者が相互に影響を及ぼし行動を拘束しあってい る状態の程度が表わされていると考えられる. 特に, 位 相が 1 から 2 に変化する点は, 歩行者の到着がランダム な状態でなくなることを表わしており，歩行の自由性に ついて考察する際に 1 つの指標となると思われる.

\section{6. 歩行者の追越し現象}

本章では前章で述べたような到着分布形状が生じる背 景となると考えられる歩行者の追越し現象について述べ ることとする.

\section{（1）歩行者の追越し現象解析の意義}

自動車交通においては, 追越し挙動は交通現象の中で も他車に与える影響がもっとも大きく，しかも危険性の 高い現象である．この挙動が拘束されると結局交通流全 体としての速度低下を起こし, 混雑のもととなる ${ }^{22)}$. そ こで, 自動車の追越し特性は交通流解析の主要なテーマ の 1 つとなり, 数多くの研究がなされている. しかし, 追越し現象の観測は大がかりになるわりにデータの収集 効率はよくないから, 実測例は多くない. 一方, 歩行者 交通はトリップ長が短く, 各歩行者の歩行速度およびそ の差も小さく, 追越しに危険を伴うこともない. しかし， 追越し挙動が制限されてくると, 歩きにくい状態となる から, 追越しの困難が巨視的な視点でとらえた歩行者の 流れに, どのような影響を与えるかを解明するととも に, 以下に述べるように, やや低密度の状態に拉いて 「歩きやすさ」といった観点から分析することは, 興味 深いものとなると思われる.

\section{（2）追越しの定義}

歩行者の追越し現象の実測は, 測定区間長がそれほど 長くなくてもよいから, 歩行者の流れを鳥瞰できる位置 から撮影したフィルムを用いて行うことができる.この フィルムを解析するにあたり, 追越しを次のように定義 した.

ある歩行者に対して, その人よりも測定区間（区間 長 : $20 \mathrm{~m}$ ) に早く到着し, しかも, 測定区間を出るのが その人よりも遅い歩行者が存在する場合に, その歩行者 は追越しをしたとする.

\section{（3）歩行者密度からみた追越し挙動}

a）追越し人数と密度の関倸

各データについて, それぞれの歩行者の追越しの有無 を調べると， $20 \mathrm{~m}$ の測定区間で追越しをした人数が求 められる.ここで追越し率を次のように定義した。

追越し率 $[1 / 20 \mathrm{~m}] *=\frac{\text { 追越しをした人数 }[\text { 人/分 } / 20 \mathrm{~m}]}{\text { 歩行者交通量 (人/分) }}$ この追越し率と密度の関係を 2 種類の幅員の場合につい て示すと図一13 のようになる. 幅員が 3.5 4.5 m の

* $20 \mathrm{~m}$ の区間で追越しの有無を判定しているので，単位長さ 当りに換算するのは妥当でない. 


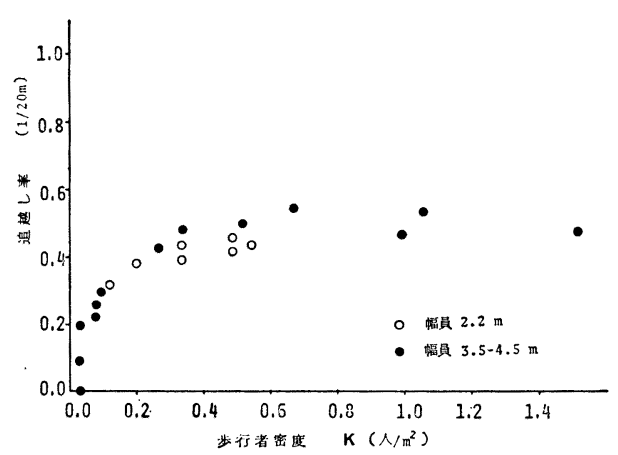

図一13 歩行者密度と追越し率

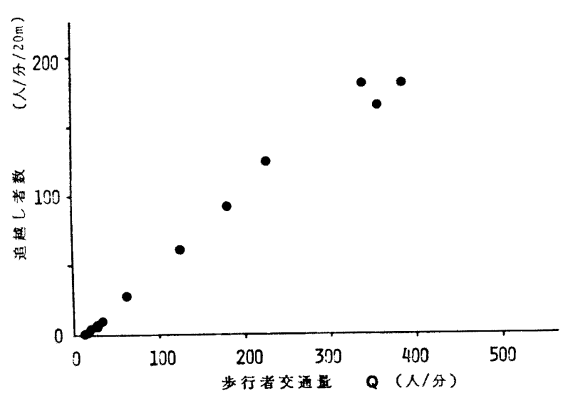

図一14步行者交通量と追越し者数

場合には, 密度が 0.2 人 $/ \mathrm{m}^{2}$ 程度までは追越し率は増加 するが，それ以上は 1.5 人 $/ \mathrm{m}^{2}$ までほぼ一定で約 0.5[1/ $20 \mathrm{~m}]$ となる.幅員が $2 \mathrm{~m}$ 程度の場合には 0.4 0.45[1/ $20 \mathrm{~m}]$ でほぼ一定となっている.また，追越し者数と交 通量の関係を示すと図一14 のようになる（幅員 3.5 $4.5 \mathrm{~m}$ の場合). 図一13 で追越し率が一定值に達するま での範囲では追越し現象が急激に増加しているように思 える.しかしながら, これらの各点の交通量は 40 人/分 以下であり，図一14より，この範囲では実際には追越 しはほとんど行われていないことがわかる.

b）追越し回数と密度の関倸

自動車交通においては, 高速車が低速車を自由に追越 せる状態ならば，追越し回数 $(N)$ と交通量 $(Q)$ の間 には，次式の関係が成立することが理論的にも，また実 測からも求められている ${ }^{23), 24) . ~}$

$$
N \propto Q^{2}
$$

同じような関倸が歩行者交通においても成立し，歩行者 が相互に拘束されずに自由に歩行できる状態にあるなら ば，追越し回数 $(N)$ と交通量 $(Q)$ の間にはこの関係 が成立するといえる，そこで，式（6）が成立する範囲 と成立しない範囲との境界を求めれば，その境界で「歩 きやすさ」の状態が変化すると考えられる.

しかし実際上,フィルムを解析する場合に, 追越し回 数を肉眼で数えることは非常に困難である. そこで，シ ミュレーションモデルを作成し, 追越し人数から追越し
回数への変換を行うことにした．ただし，追越しを行う ときの歩行者の詳細な挙動については, 必ずしも十分に は把握されていないので，図一15 に示す簡易モデルを 用いることとした。

すなわち，各歩行者はそれぞれの通行レーンを歩くも のとし, 歩行速度や到着人数については, 各密度におけ る実測から得られた分布形に従らものとした.このよう にして $20 \mathrm{~m}$ の区間における各歩行者の追越しの有無を 判定し, 追越し率と密度の関係でモデルの検証を行って 追越し回数を求めた.

図一16 に実測值とシミュレーション值を示している が, 両者はかなりよく適合している.このようにして求 めた追越し回数と交通量の関係は 図一17に示すとおり である.ただし， 1.5 人 $/ \mathrm{m}^{2}$ までのデータが得られてい る幅員が 3.5 4.5 m の場合についてであり, 式 (6)の 関係を視覚的に見やすくするために, $Q$ と $\sqrt{N}$ の関係 で示した. $Q$ と $\sqrt{N}$ が比例している範囲は交通量が 250 人/分 程度までであり, その後は追越し回数の増加 率は減少している.この交通量はお捄よそ 0.8 人 $/ \mathrm{m}^{2}$ の

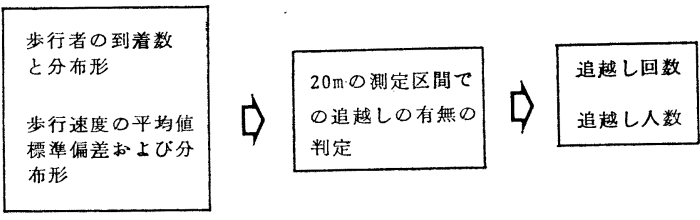

図一15 シミュレーションモデルの概要

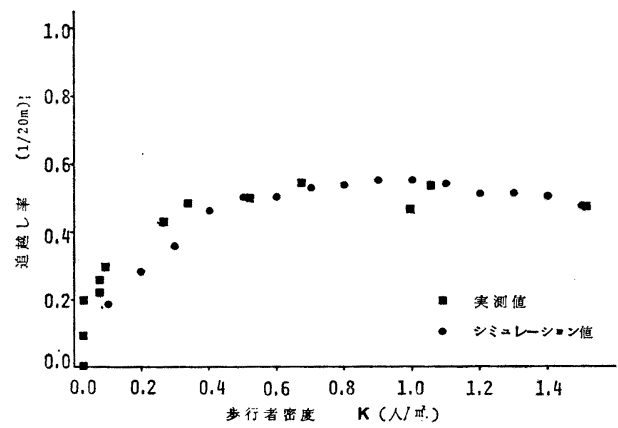

図一16 歩行者密度と追越し率

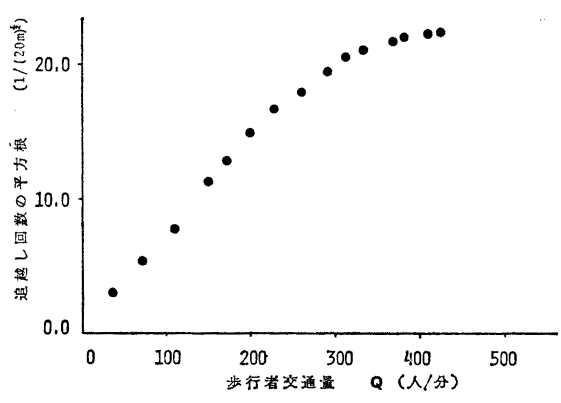

図一17 歩行者交通量と追越し回数 
密度に相当しており, これは, 歩行者の到着分布がポア ソン分布から $l=2$ のアーラン型の分布に移行する密度 にほぼ一致している．したがって， 0.8 人 $/ \mathrm{m}^{2}$ 程度の密 度で歩行の自由性が拘束されはじめると考えることがで きる.

\section{7. 歩行路のサービス水準について}

\section{（1）歩行環境についての考え方}

歩行環境について総合的に考える場合には，歩行の安 全性, 快適性, 保健性, 利便性といった視点から検討す ることが必要である.これらは相互に関連しているが， 安全性はもっとも上位に位置付けられるべきであり, 快 適性以下は不安なく歩けるといら状態のもとで検討され なければならない，環境の評価基準を作成するといら立 場からは，個々の計画に抏いて妥当なものが採用できる ように, 安全性とその他の 3 項目とのそれぞれについて 考えておけばよいであ万う。このような観点から, 安全 性が確保されたうえでの快適性に限定して述べることに する.さらに, 快適性について考える場合には, 対象と なる空間の機能に留意する必要がある. 移動空間として の性質が強い空間と，遊歩道のようにそこを歩くこと自 体が目的であるような空間を, 同じ評価基準で評価する のは無理があると思われるからである. 前者で問題とな るのは主として「歩きやすさ」であるが，後者では「歩 きや寸さ」に加えて，「景観」であるとか「雾囲気」で あるといったより高度な快適性が要求されるであろら。 ここでは，前章までに述べた事項からアプローチ可能な 「歩きやすさ」といら側面から, 歩行路のサービス水準 について検討することとしたい．

このような観点に立てば，お抢むね自動車交通に関す るサービス水準 ${ }^{25)}$ と類似した考え方を用いることができ る.考慮されるべき要因は,

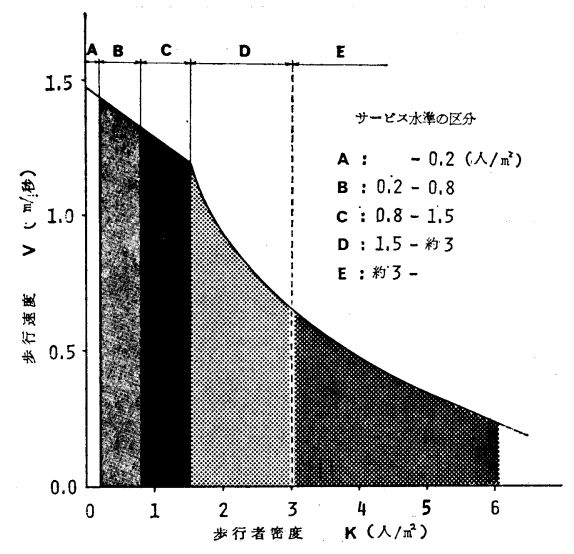

图一18 歩行路のサービス水準 a） 速度の維持

・歩行速度の平均值が大幅には低下しないこと

b) 行動の自由さ

- 希望速度を維持するために他の歩行者を追越す必要 がないこと

・速度の遅い歩行者を追越せること

c）横断の容易さ

・歩行者の流れを乱れさせることなく横断できること

\section{（2）サービス水準の設定}

前章までに述べたことを整理すると，

a）平均歩行速度は密度が 1.5 人 $/ \mathrm{m}^{2}$ を越えると急激 に低下寸る。

b) 1.5 人 $/ \mathrm{m}^{2}$ 以下の範囲では, 密度の増加に伴い, 速度の平均值が徐々に低下寸るが, 平均値のまわり の変動は平均值の低下の度合よりもさらに小さくな っていく.

c）交通量が最大となるのは $3 \sim 4$ 人 $/ \mathrm{m}^{2}$ 付近であり， その後は完全な拘束歩行状態となる.

d）歩行者の到着分布がランダムでなくなるのは, 幅 員 $3.5 \sim 4.5 \mathrm{~m}$ の歩道では 0.8 人 $/ \mathrm{m}^{2}$ 程度, 幅員約 $2 \mathrm{~m}$ の歩道では $0.2 \sim 0.3$ 人 $/ \mathrm{m}^{2}$ の密度である.

e）追越し回数と交通量の自乗とが比例するのは 0.8 人 $/ \mathrm{m}^{2}$.までであり, それ以上の密度では追越しの自 由性が徐々に失われていく（幅員 $3.5 \sim 4.5 \mathrm{~m}$ の場 合).

f） 0.2 人 $/ \mathrm{m}^{2}$ 以下では追越しをしなくてもほとんど 速度維持に影響しないが, 0.2 人 $/ \mathrm{m}^{2}$ 以上では速度 を維持するためには, 追越しが必要であると思われ る(幅員 $3.5 \sim 4.5 \mathrm{~m}$ の場合).

サービス水準について考える場合には, 歩道幅員を中 心とした道路条件と, 混雑度などの交通条件を考慮しな ければならないが，ここでは比較的広い幅員の歩道での サービス水準を, 幅員 $3.5 \sim 4.5 \mathrm{~m}$ の歩道のデータに 基づいて, 次のように設定した.
$\mathrm{A}: 0.2$ 人 $/ \mathrm{m}^{2}$ 以下
ほぼ自由歩行に近い状態
B : $0.2 \sim 0.8$ 人 $/ \mathrm{m}^{2}$ 追越しがかなり自由にでき る状態
C : $0.8 \sim 1.5$ 人 $/ \mathrm{m}^{2}$ 追越しがやや拘束された状 態
$\mathrm{D}: 1.5 \sim$ 約 3 人 $/ \mathrm{m}^{2}$ 速度低下が著しく, 拘束さ れた歩行状態
$\mathrm{E}:$ 約 3 人 $/ \mathrm{m}^{2}$ 以上 完全に拘束された歩行状態 さて, 本論では一貫して歩行者密度を基礎として分析 してきたので, サービス水準も密度で表現してある.し かし, 計画と関連づけるためには交通量で表現した方が 便利であるから，交通量の概略值に換算して示すと次の 
ようになる。
$\mathrm{A}: \sim 20$ 人/分 $/ \mathrm{m}$
B : 20〜60人 $/$ 分 $/ \mathrm{m}$
C : 60 100 人/分 $/ \mathrm{m}$
$\mathrm{D}: 100 \sim 115$ 人/分 $/ \mathrm{m}$
$\mathrm{E} ：($ 交通量は $\mathrm{D}$ レベル以下となる)

な拉， $K=1.5$ 人 $/ \mathrm{m}^{2}$ に対する交通量は，式 (2), 式 (3) がそれぞれ 1.5 人 $/ \mathrm{m}^{2}$ 以下およびそれ以上のデータ について別々に求められた回帰式であるから, 若干異な るわけであるが，便宜上，両者の平均値とした．

このようなサービス水準を実際の計画に適用するため には，設計基準といったものを考えておく必要がある. $\mathrm{D} \cdot \mathrm{E}$ レベルは拘束の度合が非常に強いから，設計に用 いるレベルは $\mathrm{A} \sim \mathrm{C}$ と考えるべきであろう． $\mathrm{A} \sim \mathrm{C}$ レベ ルの選択に関しては, より高いレベルが望ましいのはい らまでもないが，B レベルを一応の計画目標とし，ター ミナル等の混雑する場所では局所的に C レベルとなるの を許容するといったところが，現実的にみて妥当ではな いかと思われる．ただし，歩行者の交通量は短時間にお ける変動も大きいから，それぞれの場所の変動特性を考 慮する必要があろう。

2 章で述べたように，これまでにも歩行路のサービ ス水準についての提案が行われている. Oeding ${ }^{11)}$ と Fruin ${ }^{12)}$ は $15 \sim 18 \mathrm{ft}^{2} /$ 人 から $35 \sim 36 \mathrm{ft}^{2} /$ 人 $(0.30 \sim$ 0.31 人 $/ \mathrm{m}^{2}$ から $0.60 \sim 0.72$ 人 $/ \mathrm{m}^{2}$ ) あたりのレベルま でが許容できる範囲 $\left(35 \sim 36 \mathrm{ft}^{2} /\right.$ 人 以上はもっとも高い レベル）としており，これは本稿ではほぼBレベルに相 当している. Pushkarev と Zupan ${ }^{14)}$ はこのレベルがま だかなり拘束された状態であるとし，40 $\mathrm{ft}^{2} /$ 人上上 (0.27人 $/ \mathrm{m}^{2}$ 以下) の範囲をさらに細分して高水準のサ ービスレベルを提案している.

本稿では通勤時の歩行者を対象としたから，その結果 を商店街等の歩道の設計に直接利用するには無理がある かもしれない．また，歩道はいろいろな交通目的の歩行 者が通行する空間であるから，たとえ，通勤時に混雑す る歩道であっても，通勤時のデー夕に基づいて設計する のは必ずしも適切でないかもしれない，しかしながら， 最低限確保すべき水準を求めるという意味で, 通勤時の 歩行者を対象とすることは重要であると考える.

\section{8.むすび}

本稿では，歩行者の挙動について巨視的および微視的 な視点からその特性を把握するとともに，サービス水準 についても若干の考察を行ってきた. 前章において一応 のまとめは行ったから，今後の課題について整理してお $<$.
（1）歩行者流動については，速度低下が急激になる 密度における 流れの内部構造を明らかにする必要があ 万.

（2）歩行環境を「歩きやすさ」といら観点からとら え，その際に追越し現象等の解析による客観的なデータ を用いたが，それらが歩行者の主観的な意識とどのよう に対応するかを検討することが必要である.

（3）幅員 3.5 4.5 m の歩道のデータを用いてサー ビス水準を設定したから，これらは比較的広い歩道の幅 員決定に一つの方法を与えるものであるが，狭幅員の歩 道については別に検討すべき課題となるであろう.

最後に, 本研究を進めるにあたり有益なご助言をいた だいた近畿大学三星昭宏講師, ならびに調查, 分析に協 力いただいた山本久夫氏（元大阪大学学生, 現森本組) に謝意を表する次第である.

\section{参 考 文 献}

1）木村幸一郎, 伊原貞敏：建築物内に於ける群集流動状態 の観察，建築学会大会論文集，1937, pp. 307 316.

2）伊藤 滋: 省線電車駅における旅客施設の設計について, 学位論文, 1947 .

3） 戸川喜久二 : 群集流の観測に 基く避難施設の研究，建築 研究報告, 1955 .

4）宮田一: 列車運転になぞらえた歩行の人間工学的考察, 第 6 回鉄道 OR 論文集, 1966, pp. 134 149.

5) 浅井新一郎: 歩行者の通行位置に関する研究, 第 5 回日 本道路会議, 1959 , pp. 823 825.

6) 竹内伝史, 岩本広久: 細街路における歩行者挙動の分析, 交通工学, Vol. 10, No. 4, 1975, pp. 3 14.

7) Hankin B.D., Wright R.A. : Passenger flow in subways, Operational research quarterly, Vol. 9, No. 2, 1958 , pp. $81 \sim 88$.

8) Older, S.J. : Movement of pedestrians on footways in shopping streets, Traffic engineering and control, Vol. 10, No. 4, 1968, pp. 160 163.

9) Navin F.P.D., Wheeler R.J. : Pedestrian flow characteristics, Traffic engineering, Vol. 39, No. 9, 1969, pp. $30 \sim 36$.

10) O'flaherty C.A., Parkinson M.H. : Movement on a city centre footways, Traffic engineering and control, Vol. 13, No. 10, 1972, pp. 434 438.

11) Oeding D. : Verkehrsbelastung und Dimensionierung von Gehwegen und anderen Anlagen des Fussgaengerverkehrs, Strassenbau und Strassenverkehrstechnik, Nr. 22, 1963.

12) Fruin J.J. : Design for pedestrians; A level-of-service concept, Highway research record, No. 355, 1971, pp. 1 15.

13) Bovy $\mathrm{Ph} . \mathrm{H}$. : Espaces et réseaux piétonniers, Strasse und Verkehr, Nr. 7, 1974, pp. 371 378.

14) Pushkarev B., Zupan J.M. : Capacity of walkways, Transportation research record, No. 538, 1975, pp. $1 \sim 15$.

15) Hoel L.A. : Pedestrian travel rate in central business districts, Traffic engineering, Vol. 38, No. 4, 1968, pp. $10 \sim 13$.

16) Henderson L.F. : The statistics of crowd fluids, Nature, Vol. 229, 1971, pp 381 383. 
17) Henderson L.F., Lyons D.J. : Sexual differences in human crowd motion, Nature, Vol. 240, 1972, pp. $353 \sim 355$.

18) Henderson L.F., Jenkins D.M. : Response of pedestrians to traffic challenge, Transportation research, Vol. 8, No. 1, 1974, pp. $71 \sim 74$.

19) Henderson L.F. : On the fluid mechanics of human crowd motion, Transportation research, Vol. 8, No. 6,1974 , pp. $509 \sim 515$.

20）西坂秀博: 歩道幅員に関する研究, 交通工学, Vol. 10, No. 5,1975 , pp. $23 \sim 34$.

21）西田俊夫 : 待ち行列の理論と応用, 朝倉書店, $1971, \mathrm{p}$. 63.

22）交通工学研究会: 交通工学ハンドブック, 技報堂, 1973, p. 131.

23) Wardrop J.G. : Some theoretical aspects of road traffic research, Road paper 36, Proc. of Institute of civil engineers, 1952.

24）高速道路調查会： 6 車線区閒の運用に関する走行実態調 査報告書, 1969 .

25）交通工学研究会 : 道路の交通容量, 技報堂, 1968 .

26）日本自動車工業会：歩行行動に関する研究報告書， 1975 .

27）毛利正光, 塚口博司, 山本久夫 : 歩道内の歩行者挙動に 関する研究, 土木学会関西支部年次学術講演概要, 1976.

28）塚口博司, 毛利正光: 歩行者流の特性に関する研究, 土 木学会第 31 回年次学術講演会講演概要集, 1976, pp. 171 $\sim 172$.

(1977.2.22 - 受付) 